\title{
Studi Perbandingan Proses Penerimaan Mahasiswa Baru di Universitas Hasyim Asyari Tebuireng Jombang antara Teknik Komunikasi Online dan Interpersonal Tahun Akademik 2019/2020
}

\author{
Siti Fatimah dan Redi Panuju* \\ Ilmu Komunikasi, Universitas Dr. Soetomo Surabaya, Indonesia \\ *redipanuju@gmail.com
}

\begin{abstract}
Abstrak
Peneliti bermaksud untuk mengetahui implementasi dan perbandingan antara teknik komunikasi online dan komunikasi interpersonal terhadap layanan penerimaan siswa baru. Penelitian ini dilakukan dengan menggunakan metode kualitatif termasuk analisis deskriptif dengan purposive sampling. Subjek penelitian adalah pendaftar mahasiswa baru Universitas Hasyim Asy'ari (UNHASY) pada tahun akademik 2019/2020 dari 1.345 pelamar untuk Angkatan I, II, III dan IV. Para peneliti mengambil 30 informan untuk melakukan wawancara. 10 informan dari pelamar melalui komunikasi online, 10 dari pelamar melalui komunikasi interpersonal dan 10 dari petugas layanan dan komite Penerimaan Mahasiswa Baru (PMB). Hasil dari penelitian menunjukan pelayanan PMB dalam melakukan pendaftaran sehingga membutuhkan waktu yang lama untuk menunggu konfirmasi dari petugas pelayanan. Sedangkan pendaftaran melalui komunikasi interpersonal tidak terdapat kendala, proses pendaftaran cepat dan informasi yang didapatkan lebih jelas karena bertatapmuka secara langsung dengan petugas pelayanan. Meski terdapat kendala pada pendafataran melalui online UNHASY Tebuireng Jombang harus tetap meningkatkan sistem pelayanan PMB.
\end{abstract}

Kata kunci: komunikasi online, interpersonal, layanan penerimaan siswa baru.

\section{Identitas Artikel:}

Fatimah, S., \& Panuju, R. (2020). Studi Perbandingan Proses Penerimaan Mahasiswa Baru di Universitas Hasyim Asyari Tebuireng Jombang antara Teknik Komunikasi Online dan Interpersonal Tahun Akademik 2019/2020. Jurnal Ilmu Pendidikan (JIP) STKIP Kusuma Negara, 12(1), 78-89.

\section{PENDAHULUAN}

Dunia pendidikan saat ini menduduki peringkat tinggi yang sangat diapresiasi oleh masyarakat. Semakin banyak siswa- siswi yang melanjutkan sekolahnya dari mulai tingkat dasar hingga menengah keatas. Kemudian dilanjutkan lagi ke jenjang Perguruan Tinggi (PT), perkembangan untuk melanjutkan ke PT semakin meningkat dari tahun ke tahun. Bisa dibuktikan dengan adanya seleksi pendaftaran PMB mulai dari seleksi bidikmisi, LPDP, SMPTN, SBMPTN dan berbagai macam jalur lainnya calon mahasiswa sudah melakukan pendaftaran sebelum Ujian Nasional dilaksanakan.

PMB merupakan proses dalam melayani calon mahasiswa baru (CMB) untuk melakukan pendaftaran. Setiap PT membuka pendaftaran CMB dengan memberikan pelayanan yang baik kepada calon pendaftar. Hal ini sangat penting 
karena proses awal berjalannya akademik dimulai dari PMB untuk menyeleksi CMB yang akan masuk ke dalam PT. Pelayanan menurut Kitchroen (2004) bahwa kualitas pelayanan yang buruk akan berpengaruh terhadap sektor pendanaan dan kelangsungan hidup PT melalui penurunan popularitas institusi dan penurunan jumlah standar pendaftar, meskipun dampak tersebut terjadi secara tidak langsung dan dalam jangka waktu yang lama.

Salah satu kegiatan pelayanan dalam lingkup PT yaitu PMB, yaitu merupakan proses bisnis awal yang selalu dilakukan setiap tahun oleh PT untuk mendapatkan mahasiswa baru. Hampir seluruh PT telah memanfaatkan teknologi komunikasi untuk mendukung proses tersebut. UNHASY juga telah menggunakan teknologi komunikasi untuk menjalankan proses PMB yang terdapat dua pelayanan dalam melakukan pendaftaran, yaitu pelayanan menggunakan komunikasi online dan komunikasi interpersonal. Seiring dengan perkembangan teknologi informasi (information technology), seorang individu dapat berkomunikasi secara online (online communication) yaitu berkomunikasi secara langsung dengan orang lain melalui internet (Valkenburg \& Peter, 2007). Mereka dapat merasakan kemudahan untuk berkomunikasi online tanpa harus bertatap muka dengan orang lain. Melalui komunikasi online, seseorang dapat mengembangkan persahabatan dengan orang lain.

Menurut Littlejohn \& Foss (2010), komunikasi antar pribadi (interpersonal communication) adalah komunikasi antar individu-individu. Sedangkan menurut Hardjana (2003), komunikasi antar pribadi adalah interaksi tatap muka antar dua atau beberapa orang, dimana pengirim dapat menyampaikan secara langsung. Arni (1995) menyatakan bahwa komunikasi antar pribadi adalah proses pertukaran informasi diantara seseorang dengan orang lain yang dapat langsung diketahui balikannya. Para Ahli teori komunikasi mendefinisikan komunikasi antar pribadi secara berbeda-beda (Wiryanto, 2006; Widjaya, 2000). Dalam hal ini komunikasi interpersonal dilakukan antara dua orang atau lebih secara tatap muka antara CMB dengan petugas pelayanan PMB untuk saling mendapatkan informasi yang dibutuhkan. Untuk mewujudkan persepsi yang baik (positif) dari konsumen (CMB) suatu PT perlu memperhatikan kualitas pelayanan. Kualitas merupakan kecocokan, perbaikan berlanjut, bebas dari kerusakan, dan pemenuhan kebutuhan pelanggan sejak awal hingga akhir serta sesuatu yang bisa membahagiakan pelanggan (Hardiyansyah, 2018; Sari, 2017).

PT dipilih dalam penelitian ini adalah UNHASY Tebuireng Jombang. Sebagai mana diketahui, selain kampus berbasis pesantren dan entrepreneurship juga mendapatkan peringkat mahasiswa terbanyak dari PT yang berada di lingkungan Jombang. Diharapakan hasil penelitian ini akan bisa memberikan rekomendasi bagi UNHASY dalam upaya meningkatkan kualitas pelayanannya. UNHASY sebagai salah satu organisasi layanan publik, tentu juga memiliki tantangan yang sama dengan PT umum lainnya. UNHASY mengalami kondisi yang sama, sehingga harus memikirkan strategi peningkatan pelayanan yang memberi kepuasan kepada mahasiswa. Tujuan penting dari suatu instansi pendidikan yaitu memberikan kebahagian (perasaan senang) pada konsumen akan pelayanan.

Pelayanan yang memiliki tingkat kualitas tinggi yaitu pelayanan yang dapat memenuhi kebutuhan dan harapan pengguna jasa dalam hal ini mahasiswa atau CMB. Kualitas pelayanan harus dimulai dari kebutuhan dan berakhir pada tanggapan pengguna jasa. Parasuraman, Zeithaml \& Berry (2002) menyatakan 
bahwa kualitas pelayanan adalah perbandingan antara pelayanan yang diharapkan konsumen dengan pelayanan yang diterimanya. Penilaian menyeluruh terhadap keunggulan dari kualitas pelayanan dipersepsikan baik dan memuaskan, tetapi sebaliknya jika pelayanan yang diterima lebih rendah dari yang diharapkan maka kualitas pelayanan dipersepsikan buruk (Hermanto, Sugiana \& Agustin, 2019). Komunikasi juga merupakan keterampilan yang akan menentukan bagaimana khalayak sebagai pelanggan dalam memproses dan mencitrakan organisasi pemberi pelayanan.

Komunikasi (communication) berasal dari bahasa latin yaitu communication yang berarti pemberitahu atau pertukaran. Kata Sifatnya communis, yang bermakna umum atau bersama-sama (Wiryanto, 2006). Para pakar ahli ilmu komunikasi mendefinisikan ilmu komunikasi secara berbeda-beda. Lasswell (1948) membuat definisi yang cukup popular yaitu who says what in which channel to whom with what effect (Siapa mengatakan apa dengan saluran apa kepada siapa dengan efek bagaimana). Kemampuan dalam melakukan komunikasi adalah bagian terpenting dari kehidupan, karena dengan berkomunikasi anak dapat mengekspresikan perasaan dan mengungkapkan ide serta pemikirannya.

Dalam melakukan komunikasi manusia mempunyai banyak media untuk saling menyampaikan informasi dan mendapatkan informasi atau pesan yang diinginkan. Komunikasi manusia ialah komunikasi yang mengisyaratkan penyampaian pesan searah dari seseorang atau suatu lembaga kepada seseorang (sekelompok orang) lainya, baik secara langsung tatap muka ataupun melalui media, seperti surat (selebaran), surat kabar, majalah, radio, atau televisi (Wiryanto, 2006).

Komunikasi terbagi menjadi dua yakni komunikasi online dan komunikasi interpersonal. Pakar ilmuan umumnya sepakat bahwa yang dimaksud dengan komunikasi antarpribadi (interpersonal communication) adalah komunikasi yang dilakukan antara dua orang secara tatap muka. Variasinya masing-masing menangkap reaksinya secara langsung (Rakhmat \& Mulyana, 2010), bisa melakukan secara verbal maupun non verbal (Devito, 1997), unsur-unsur pribadi (Miller \& Steinberg, 1975), dalam suasana yang memungkinkan di antara keduanya berbicara secara langsung (Pearson, Child, DeGreeff, Semlak \& Burnett, 2011), bisa terjadi komunikasi antar dua orang atau diadik dan bisa juga dalam kelompok kecil (Nurudin, 2020). Berdasarkan pengertian di atas dapat ditarik esensinya, komunikasi interpersonal bila dilakukan oleh dua orang. Satu orang menjadi komunikator dan satunya menjadi komunikan (Panuju, 2018). Komunikasi interpersonal lebih efektif berlangsung jika berjalan secara dialogis, yaitu antara dua orang yang saling menyampaikan dan memberi pesan secara timbal balik (Arnesti \& Hamid, 2015).

Menurut Kurnia (2017), penjelasan internet adalah sebuah medium terbaru yang mengkorvengesikan seluruh karakteristik media dari bentuk-bentuk terdahulu. Apa yang membuat bentuk-bentuk komunikasi berbeda satu sama lain bukanlah penerpaan aktualnya, namun perubahan dalam bentuk komunikasi seperti kecepatan komunikasi, harga komunikasi, persepsi pihak-pihak komunikasi, fasilitas mengakses komunikasi, densitas (kepekaan dan kepadatan) dan kekeayaan arus-arus informasi. Titik keunikan internet sendiri terletak pada esensinya sebagai sebuah medium (Arnesti \& Hamid, 2015). 
Nasrullah (2018) menjelaskan bahwasanya definisi yang terjadi pada komunikasi diantara dua orang secara bertatap muka sangat berbeda dengan komunikasi yang termediasi komputer atau computer mediated communication. Identitas apa yang direpresentasikan di dunia nyata belum tentu dapat didekati melalui teorinya dalam melihat fenomena identitas di dunia virtual (Arnesti \& Hamid, 2015).

Maka dengan demikian internet berperan penting dalam membantu manusia dalam memberikan atau mendapatkan informasi. Eko mengemukakan dalam buku simulasi digital bahwa istilah "komunikasi online" mengacu pada membaca, menulis, berbagi video kamera dan komunikasi melalui jaringan komputer. Komunikasi virtual atau komunikasi melalui jaringan komputer. Komunikasi virtual atau komunikasi onlineadalah cara berkomunikasi dimana penyampaian pesan dilakukan dengan melalui cyberspace atau biasa disebut dengan dunia maya (Arnesti \& Hamid, 2015).

Dalam beberapa kasus, seperti pemasaran politik melalui media televisi dan media online, penggunaan metode online cukup efektif dalam memperkenalkan produk, tetapi tidak menjamin mempengaruhi perilaku. Penelitian terhadap iklan Partai Indonesia Raya (Perindo) yang dilakukan Panuju (2019a), menunjukan Perindo mencapai popularitasnya menjelang pemilu hamper menembus angka 6\%, namun hasil pemilu 2018 partai ini tidak lolos ambang batas (kurang dari 3\%). Hal ini menunjukan bahwa kecanggihan teknologi tidak selalu berkorelasi dengan penerimaan komunikasi (adopasi).

Ini berate penggunaan media online membutuhkan persyaratan tertentu untuk memperoleh hasil yang maksimal, misalnya disebut Panuju (2019b) kesiapan sumber daya manusia untuk menjalankan operasi teknologi informasi, juga kemuktahiranteknologi itu sendiri, serta kesiapan komunikan (khalayak) dalam menggunakan teknologi informasi, khususnya internet. Sebab di desa-desa masih banyak ditemukan individu yang gagap teknologi. Inilah masalah yang hendak diteliti dalam kasus penggunaan media online dalam penerimaan siswa baru di UNHASY, Tebuireng Jombang, Jawa Timur.

Definisi pelayanan ialah bagian dari komunikasi yang termasuk komunikasi secara online. Komunikasi melalui online (internal e-mail dan internet) merupakan sarana yang murah, cepat dan efisien. Keuntungan dari media ini adalah bantuan dan fasilitas yang disediakan sangat lengkap secara online. Komunikasi melalui online telah merevolusi cara kerja dengan menyediakan cara cepat, murah, dan efisien. Pengguna dapat menyimpan file dan berinteraksi lebih mudah dan cepat. Komunikasi online juga dapat dengan mudah diedit dan dibagi antara tim karyawan yang bekerja bersama-sama. Sebagai contoh, rincian rekening pelanggan dapat diakses, baik dikantor lokal maupun kantor cabang secara bersamaan. Pesan nonverbal dapat berupa gambar yang ditransmisikan melalui posting di internet juga dengan mudah dibagikan dengan rekan kerja (Ginting, 2017).

Obrolan online (online chat) merupakan segala bentuk komunikasi yang menggunakan Internet, tetapi secara spesifik mengacu pada obrolan atau percakapan berbasis teks antara dua pengguna di Internet. Obrolan daring dapat menggunakan perangkat lunak seperti pengirim pesan instan, Internet Relay Chat, dan lain-lain. 
Sedangkan pelayanan komunikasi melalui online yang terdapat dalam PMB di UNHASY menggunakan alat komunikasi handphone atau personal computer (PC)/laptop yang dapat mengakses melalui website dan social media. Adapun social media yang digunakan adalah social media Instagram (IG) dan WhatsApp (WA).

Handphone adalah alat komunikasi yang dikenal juga dengan telepon genggam. Handphone dalam hal ini adalah sarana atau perangkat teknologi informasi dan telekomunikasi yang menggabungkan beberapa fungsi teknologi menjadi satu. Sedangkan komputer PC adalah alat yang dipakai untuk mengolah data menurut prosedur yang telah dirumuskan/system yang ada. Laptop atau komputer jinjing atau notebook, merupakan sebuah mobile computer yang berukuran relative kecil dan ringan. Beratnya berkisar 1-3 kg, tergantung ukuran, bahan, dan spesifikasi laptop tersebut (Setyaji, 2010).

Pelayanan dalam komunikasi interpersonal dilakukan secara tatap muka antara dua orang atau lebih untuk memberikan informasi kepada komunikan. Komunikasi interpersonal sering kita jumpai dalam kehidupan sehari-hari. Biasanya hal ini terjadi dalam suasana informal dan tatap muka (face-to-face), misalnya tegur sapa dengan teman atau ucapan yang bersifat spontan dan tidak menggunakan tata bahasa baku. Komunikasi interpersonal adalah sebuah proses yang melibatkan pengiriman dan penerimaan pesan (Patton \& Giffin, 1981). Dalam komunikasi interpersonal, terdapat proses penyampaian berita yang dilakukan oleh seseorang kemudian berita tersebut diterima oleh orang lain atau sekelompok kecil orang guna mendapatkan umpan balik (Devito, 1997).

Littlejohn \& Foss (2010) menyebutkan lima kriteria komunikasi interpersonal, yakni harus ada dua orang yang saling menyadari keberadaannya, masing-masing saling ketergantungan dan mempengaruhi, pesan-pesan merupakan hasil dari hubungan timbal balik (feedback), pesan-pesan dituangkan dalam bentuk verbal dan non-verbal, serta komunikasi interpersonal bersifat informal dan fleksibel.

Dengan demikian pelayanan komunikasi interpersonal merupakan proses pertukaran pesan verbal dan non verbal antara dua orang, salah satunya bertindak sebagai pengirim pesan (sender) dan lainnya sebagai penerima (receiver), guna memperoleh hubungan timbal balik (feedback).

\section{METODE PENELITIAN}

Dalam penelitian ini, peneliti akan menggunakan pendekatan kualitatif deskriptif. Pemilihan pendekatan kualitatif deskriptif ini dilatarbelakangi oleh penelitian kualitatif yang didefinisikan sebagai penelitian yang mengemukakan gambaran (description) dan/atau pemahaman (understanding) mengenai bagaimana dan mengapa suatu gejala atau realitas komunikasi terjadi. Penggambaran (description) tersebut ditujukan agar dapat memberikan pemahaman (understanding, verstehen) mengenai gejala yang terjadi.

Penelitian ini menggunakan strategi studi kasus dengan mendeskripsikan proses pelayanan PMB menggunakan komunikasi online dan komunikasi interpersonal di UNHASY. Pemilihan di UNHASY sebagai subjek penelitian dikarenakan sistem PMB menggunakan dua alternatife komunikasi yaitu komunikasi online dan komunikasi Interpersonal. 
Informan utama penelitian ini adalah mahasiswa baru UNHASY tahun 2019. Dipilih dari pendaftar online dan offline. Mahasiswa baru tersebut ialah mereka yang mendapatkan pelayanan komunikasi melalui online bagi pendaftar online dan pelayanan komunikasi interpersonal bagi pendaftar offline. Adapun unit analisa penelitian ini adalah menganalisa proses pelayanan komunikasi online dan komunikasi interpersonal oleh mahasiswa baru UNHASY.

Proses penggalian data diambil dari sumber data. Sumber data primer diperoleh dari hasil wawancara subjek penelitian, diantaranya mahasiswa baru tahun 2019, mediator, petugas pelayanan mahasiswa baru, panitia PMB dan informan pendukung yang bisa memberikan informasi penelitian ini. Data primer juga bisa diperoleh dari pengamatan dan observasi melalui cara terlibat langsung atau tidak terlibat langsung, baik tanpa atau dengan sepengetahuan subjek.

Sedangkan data sekunder merupakan data-data pendukung penelitian yang berasal dari dokumentasi berupa artikel, postingan website, kegiatan serta dokumen-dokumen lainnya yang terkait UNHASY.

Teknik pengumpulan data yang akan digunakan oleh peneliti, yaitu : Observasi, Wawancara dan dokumentasi. Dalam penelitian ini, peneliti memperoleh data atas temuan baik dari wawancara dan dokumentasi. Dalam penelitian ini, peneliti menggunakan sampel purposive (nonprobabiltas) jenis sampel ini tidak dipilih secara acak. Tidak semua unsur atau elemen populasi mempunyai kesempatan sama untuk bisa dipilih menjadi sampel. Tidak ada kriteria baku mengenai berapa jumlah responden yang harus diwawancarai.

Seperti dikemukakan oleh Mulyana (2013), purposif sampling termasuk satu dari beberapa jenis pengambilan sampel nonprobabilitas (nonprobability sampling) yang biasanya digunakan dalam penelitian kualitatif. Disebut non probabilitas, karena anada sebagai peneliti tidak bertujuan untuk menggeneralisasikan temuan penelitian.

\section{HASIL DAN PEMBAHASAN}

\section{Proses PMB Menggunakan Komunikasi Online}

Proses pendaftaran melalui komunikasi online di UNHASY menggunakan media komunikasi melalui Website PMB yaitu: pendaftaran.unhasy.ac.id dan menggunakan social media IG, Facebook (FB), Tweeter, WA dan e-mail. Media komunikasi tersebut dapat diakses memnggunakan komputer/Laptop dan Handphone dengan menggunakan jaringan internet. Berikut Alur sistem pendaftaran Online: (1) buka browser (Firefox, Google Chrome, IE) kemudian ketik URL:www.unhasy.ac.id; (2) klik link pendaftaran (Pojok Kanan Atas), sehingga anda dibawa ke halaman utama website pendaftaran online. Sedangkan cara lain adalah: (1) mengakses alamat URL: www.pendaftaran.unhasy.ac.id; (2) pada website pendaftaran, klik link DAFTAR ONLINE; (3) isi form pendaftaran dan dokumen pendukung secara lengkap dan benar, kemudian simpan; (4) cetak bukti pendaftaran; (5) mengirim berkas pendaftaran via POS atau menyerahkan 3 (tiga) hari sebelum tes; (6) mengikuti tes (dengan membawa bukti pendaftaran); (7) pengumuman hasil tes (dapat dilihat di www.unhasy.ac.id atau www.pendaftaran.unhasy.ac.id); (8) daftar ulang.

Berdasarkan alur pendaftaran di atas, adalah proses pendaftaran melalui online yang diambil melalui website pendaftaran di UNHASY. Proses Pelayanan 
Pendaftaran online di UNHASY dilakukan melalui beberapa proses tahapan. Tahapan pertama CMB melakukan pendaftaran online dengan mengisi form di website selanjutnya tahapan kedua CMB menghubungi admin sesuai contact person yang tercantum di website untuk melakukan konfirmasi dan mengirim bukti transfer pembayaran pendaftaran.

Setelah melakukan konfirmasi dan mengirim bukti transfer uang pendaftaran mahasiswa baru, petugas pelayanan memasukan data kedalam rekap data excel bagi pendaftar melalui jalur online yang sudah benar-benar melakukan pembayaran melalui transfer ke rekening UNHASY untuk pemanggilan mengikuti tes seleksi PMB. Pendaftar online yang tidak melakukan konfirmasi dengan menujukan bukti transfer pembayaran maka tidak masuk dalam pemanggilan tes seleksi PMB.

Informan dipilih secara acak dari sejumlah mahaiswa baru yang dijumpai dilapangan. Dari 10 mahasiswa tersebut yang melakukan pendaftaran online mempunyai beberapa alasan memilih pendaftaran melalui online. Salah satu diantaranya mereka yang bertempat tinggal jauh membutuhkan waktu, tenaga, dan biaya yang banyak jika melakukan pendaftaran ke kampus. Berikut beberapa hasil wawancara terhadap mahasiswa dengan pendaftaran melalui online:

"Saya memilih pendaftaran melalui online karena tempat tinggal ataupun alamat saya sangat jauh dari UNHASY, maka dari itu untuk mempermudah saya mendaftar melalui online".

"Memilih melakukan pendaftaran online karena pada saat itu saya mendapatkan saran dari pengasuh Pondok Pesantren Walisongo dan posisi saya mendadak tidak ada yang mengantar".

Beberapa dari informan menyampaikan kendala dalam melakukan mendaftaran melalui komunikasi online, salah satu diantaranya mereka mengatakan bahwa pesan yang dikirim kepada contact person membutuhkan waktu yang lama menunggu balasannya.

"Kendala yang ditemui saat melakukan pendaftaran melalui komunikasi online yaitu pesan lama terbalas sehingga membutuhkan waktu 2 hari untuk proses pendaftran online".

Komunikasi yang dilakukan CMB untuk menghubungi contact person melalui berbagai media komunikasi handphone, yang tidak hanya memberikan fasilitas komunikasi telpon dan SMS (short message service) tetapi juga media sosial WA, IG dan FB yang saat ini hampir semua orang menggunakannya di handphone masing-masing. Dari 10 informan pendaftar melalui online 7 diantaranya mengalami kendala yang sama yaitu lamanya proses pendaftarana melalui komunikasi online.

Kendala informan lainnya kebanyakan dari mereka mengungkapkan dalam proses pengisian form pendafataran di halaman web sangat cepat karena yang diisi tidak banyak. Akan tetapi ketika pengisian form pendaftaran online disimpan muncul pernyataan "Pendaftaran berhasil, silahkan tunggu password dan username melalui pesan yang dikirim di email untuk bisa login dan mencetak kartu bukti pendaftaran”. Oleh karena itu, mereka menunggu ada pesan masuk di 
email dan ketika belum ada balasan-balasan dari email mereka menanyakan ke admin contact person PMB melalui pesan media sosial WA sebagai berikut.

"Saya sudah daftar online di web tetapi sampai sekarang belum mendapat password untuk login, itu bagaiamana ya?"

Di atas adalah kutipan pertanyaan CMB yang mendapati kendala dalam melakukan pendaftran melalui komunikasi online. Mereka langsung mengirim pesan melalui sosial media WA pada kontak yang sudah tercantum di website pendaftaran untuk mencari solusi dari kendala tersebut, dan admin contact person selisih 2 menit membalas bahwa username dan password tersebut tidak digunakan untuk pendaftaran awal, akan tetapi nanti ketika melakukan daftar ulang.

Dari sini terjadilah miskomunikasi antara mahasiswa baru dengan sistem pendaftaran melalui komunikasi online. Karena keterangn pernyataan menunggu username dan password dikirim ke email itu muncul ketika mereka melakukan pendaftaran awal. Sehingga mereka menunggu pesan dari email PMB unhasy dan itu ternyata tidak ada pesan yang masuk ke email mereka.

\section{Proses Pelayanan PMB Menggunakan Komunikasi Interpersonal}

Penelitian pendaftaran melalui komunikasi interpersonal ini melibatkan 10 informan mahasiswa baru UNHASY. Informan dipilih secara acak dari sejumlah mahasiswa yang dijumpai dilapangan. Pendaftaran melalui komunikasi interpersonal ini dilakukan secara langsung bertatap muka antara CMB dengan petugas pelayanan penerimaan mahasiswa di sekretariat pendaftaran mahasiswa baru UNHASY.

Prosedur pendaftaran melalui komunikasi interpersonal ini menurut tanggapan informan sangatlah mudah dan cepat prosesnya. Karena mereka langsung bertemu bertatap mukadan membayar pebdaftran secara langsung diterima tanpa melakukan konfirmasi. Berikut ini prosedur pendaftran melalui komunikasi Interpersonal: (1) datang langsung ke sekretraiat Pendaftaran Mahasiswa Baru UNHASY di Jalan Irian Jaya No. 55 Tebuireng Jombang 61471 Jawa Timur Indonesia, Jam pelayanan 08.00-15.00 WIB; (2) menemui Petugas Pelayanan PMB untuk bertanya-tanya lebih jelas terkait pendaftaran PMB; (3) mengisi formulir pendaftaran di komputer yang sudah disediakan; (4) menyetorkan persyaratan pendaftaran yaitu fotocopy kartu keluarga 1 lembar; (5) membayar biaya pendaftaran sesuai gelombang pendafataran ke petugas pelayanan PMB; dan (6) mendapatkan kuitansi pembayaran dan kartu bukti pendaftaran.

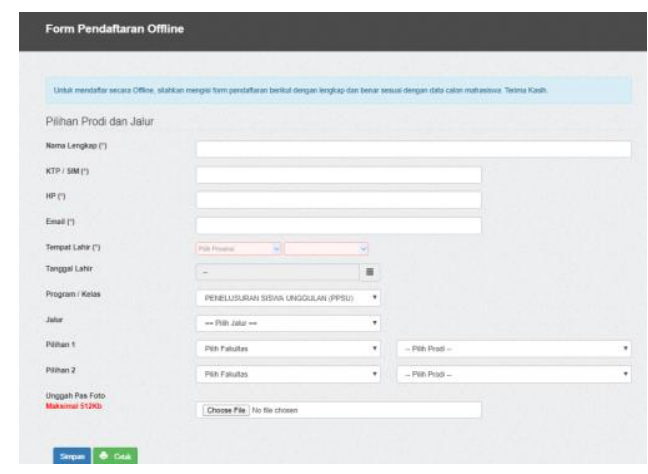

Gambar 1. Formulir Pendaftaran di Komputer 
Sesuai prosedur pelayanan pendaftaran melalui komunikasi interpersonal, ketika CMB sudah di tempat sekretariat PMB, mereka menemui petugas pelayanan untuk bertanya-tanya secara tatap muka sebelum melakukan pendafataran. setelah mereka mendapatkan informasi dari petugas pelayanan maka petugas pelayanan membantu mendamipi CMB untuk mengisi formulir di komputer sampai proses selesai yaitu mencetak kartu bukti pendaftaran.

Sesuai prosedur pelayanan pendaftaran melalui komunikasi interpersonal, ketika CMB sudah di tempat sekretariat PMB, mereka menemui petugas pelayanan untuk bertanya-tanya secara tatap muka sebelum melakukan pendafataran. setelah mereka mendapatkan informasi dari petugas pelayanan maka petugas pelayanan membantu mendamipi CMB untuk mengisi formulir di komputer sampai proses selesai yaitu mencetak kartu bukti pendaftaran.

Menurut semua informan mahasiswa yang memilih menggunakan pendaftaran melalui komunikasi interpersonal selain karena rumahnya dekat dan lebih mudah proses pendaftarannya ada informan lain yang rumahnya jauh dari untuk meuju ke sekretariat PMB UNHASY membutuhkan waktu 16 jam.

"Saya memilih pendaftaran melalui komunikasi interpersonal karena bair cepat direspon”.

Begitu pentingnya "fast response" untuk kepuasan pelanggan yang biasanya digunakan dalan dunia bisnis. Begitupun di dunia akademik dibutuhkan cepat tanggap dalam melayani mahasiswa khususnya mahasiswa baru. Selain alasan tersebut ada yang mengatakan bahwa memilih melakukan daftar menggunakan komunikasi interpersonal karena bisa mendapatkan informasi dengan lebih jelas.

Petugas pelayanan PMB terdiri dari 4 petugas setiap harinya. Mereka bertugas sesuai jadwal piket masing-masing. Jumlah keseluruhan dari petugas pelayanan di sekretariat PMB ada 14 petugas. Setiap petugas mendapati piket jaga sekretariat PMB masing-masing 2 hari. Mereka bertugas melayani dan memberikan informasi terkait pendaftaran mahasiswa baru baik melalui pendaftaran online dan melalui komunikasi interpersonal.

Pelayanan PMB di buka mulai jam 09.00 WIB, tahun lalu dibuka mulai tanggal 08.00 WIB, yang tahun 2019 ini bukanya mulai jam 09.00 WIB karena seringkali petugas masih ada kerepotan di fakultas sehingga tidak bisa tepat waktu jam 08.00 WIB. Dari hasil keterangan petugas pelayanan tersebut agar menjadi perhatian $\mathrm{CMB}$ yang akan melakukan pendafataran melalui komunikasi interpersonal maka di berikan info waktu pelayanan PMB di depan pintu sekretariat PMB "Pelayanan buka Jam 09.00-16.00 WIB". Karena pelayanan dibuka mulai jam 09.00 WIB sebagai gantinya jam kerja waktu jam istirahat jam 12.00-13.00 WIB tetap buka tanpa adanya jam istirahat. Jadi jam pelayanan PMB mulai jam 09.00-16.00 WIB tanpa ada jam istirahat. Peraturan waktu pelaksanaan pelayanan dibagi menjadi 2 sesi, shift pagi mulai jam 08.00-12.30 WIB 2 petugas dan shift siang mulai 12.30-16.00 2 petugas pelayanan PMB 2019. Sebelum proses pelayanan $\mathrm{PMB}$ dilaksanakan, $\mathrm{CMB}$ yang datang ke sekretariat seringkali mereka bertanya-tanya atau konsultasi dulu terkait prodi yang akan di ambil. Setelah selesai konsultasi mereka di pandu oleh petugas untuk mengisi form pendaftaran di komputer. 


\section{Hasil Analisis Komunikasi Online dan Interpersonal}

Teknik pengumpulan data yang digunakan dalam tesis ini adalah wawancara yaitu untuk memperoleh data primer tentang pelayanan sistem PMB di UNHASY. Wawancara dilakukan kepada pihak-pihak yang berkaitan langsung dengan kegiatan PMB diatara mereka yaitu Ketua Panitia, Koordinator Panitia, Anggota Sekretariat Pelayanan PMB dan mahasiswa baru tahun akademik 2019/2020. Selain itu peneliti juga menggunakan teknik studi dokumen yang bertujuan untuk mendapatkan data tambahan sehingga data yang terkumpul lebih akurat. Teknik ini dilakukan dengan mengamati secara mendalam mengenai kegiatan PMB melalui laporan kegiatan PMB yang disusun oleh panitia.

Setiap akhir pembubaran panitia PMB ada laporan dari masing-masing divisi panitia, salah satunya laporan dari divisi kesekretariatan untuk menganalisa pendaftar mahasiswa baru melalui online dengan melalui komunikasi interpersonal. Kemudian menganalisa alamat CMB yang mendaftar di kampus UNHASY. Berikut Tabel 1, yaitu hasil perolehan antara pendaftaran online dan offline menggunakan komunikasi interpersonal.

Tabel 1. Rincian Jumlah Pendaftar dengan Komunikasi Interpersonal

\begin{tabular}{|c|c|c|c|}
\hline Gelombang & Online & Offline & Jumlah \\
\hline 1 & 53 & 327 & 380 \\
\hline 2 & 39 & 218 & 257 \\
\hline 3 & 74 & 422 & 496 \\
\hline 4 & 23 & 189 & 212 \\
\hline Jumlah & 189 & 1156 & 1345 \\
\hline
\end{tabular}

Bahwasannya pendaftar melalui online tidak hanya mereka yang bertempat tinggal jauh begitupun pendaftar offline melalui komunikasi interpersonal tidak hanya CMB yang bertempat tinggal dekat dengan kampus. Dari total pendafatar 1.345 pendaftar, 189 pendaftar $(14 \%)$ yang menggunakan komunikasi online dan 1.156 (86 \%) pendaftar melalui komunikasi interpersonal. Mereka melakukan proses pendaftran sesuai dengan kebutuhan masing-masing. Salah satu calon mahasiswa dari aceh yang melakukan pendaftaran melalui komunikasi interpersonal, dia diantar bersama keluarganya karena ingin mengetahui langsung lingkungan kampus UNHASY dan ingin mencari tempat pondok/asrama.

\section{KESIMPULAN}

Proses pendaftaran melalui online, diakses melalui website pendafataran menggunakan laptop, komputer atau handphone yang tersambung dengan jaringan internet. Proses Pendafataran melalui komunikasi interpersonal yaitu CMB menuju ke sekretariat PMB UNHASY secara langsung mengsisi formulir pendaftaran dan melakukan pembayaran administrasi pendaftaran dengan uang cash. Seiring berkembangnya teknologi yang canggih yang seharusya pendaftaran online lebih mudah, praktis dan efisien untuk CMB melakukan pendafataran melalui online. Karena bisa memanfaatkan teknologi untuk kemudahan mereka melakukan pendaftran melalui online. Akan tetapi dengan sistem PMB yang melalui pendafataran online, terdapat miskomunikasi dari sistem tersebut yang 
mengakibatkan proses pendaftaran mahasiswa baru melalui online mengalami proses yang sangat lama.

Proses pendafataran melalui online terdapat miskomunikasi antara sistem dengan petugas pelayanan PMB atau admin contact person. Dalam sistem pendaftaran mahasiswa baru setelah CMB menyimpan formulir pendafatran melalui online dalam sistem, muncul pernyataan " Pendaftaran berhasil ! silahkan menunggu username dan password yang dikirim melalui email anda untuk login dan mencetak kartu bukti pendaftaran". Dari pernyataan tersebut sehingga CMB menunggu kiriman username dan password di email mereka. Akan tetapi selama proses menunggu tidak ada username dan password yang terkirim dari email pendaftar. Sehingga muncullah berbagai pertanyaan tentang "username dan password" melalui sosial media WA, IG, FB dan e-mail ke admin contact person pelayanan mahasiswa baru. Dengan banyaknya pesan yang masuk sehingga admin contact person tidak bisa membalas pesan pendaftar dengan cepat.

Pendafataran melalui komunikasi interpersonal tidak ada kendala dalam proses pelayanan PMB. mereka cenderung lebih suka melakukan pendaftaran melalui komunikasi interpersonal karena selain lebih jelas mereka juga bisa mengetahui lingkungan kampus UNHASY. Setelah dilakukan penelitian dan analisa data maka dapat diperoleh kesimpulan sebagai bertikut: (1) Pendafataran melalui komunikasi interpersonal lebih efektif, mudah dan jelas dari pada pendaftaran melalui online; (2) berdasarkan hasil laporan jumlah mahasiswa perbandingan antara pendafataran melalui online dan komunikasi Interpersonal. 189 CMB pendaftar online dan 1.156 pendaftar melalui komunikasi interpersonal.

\section{REFERENSI}

Arnesti, N., \& Hamid, A. (2015). Penggunaan Media Pembelajaran OnlineOffline dan Komunikasi Interpersonal terhadap Hasil Belajar Bahasa Inggris. Jurnal Teknologi Informasi \& Komunikasi dalam Pendidikan, 2(1), 85-99.

Arni, M. (1995). Komunikasi Organisasi. Jakarta: Bumi Aksara.

Devito, J. A. (1997). Human Communication. New York: Harper Collinc Colege Publisher.

Ginting, D. (2017). Komunikasi Cerdas: Panduan Komunikasi di Dunia Kerja. Jakarta: Elex Media Komputindo.

Hardiyansyah, H. (2018). Kualitas Pelayanan Publik: Konsep, Dimensi, Indikator dan Implementasinya. Yogyakarta: Gava Media.

Hardjana, A. M. (2003). Komunikasi interpersonal dan intrapersonal. Yogyakarta: Kanisius.

Hermanto, A. N., Sugiana, D., \& Agustin, H. (2019). Penyampaian Informasi Oleh Tenaga Kependidikan Pada Sub Bagian Administrasi Akademik Dalam Pelayanan Akademik Terhadap Mahasiswa Jenjang S1. In Aulianto, D.R. dkk. (Eds.) The Future of Organizational Communication In The Industrial Era 4.0. Sumedang: Aksel Media Akselerasi.

Kitchroen, K. (2004). Literature review: Service quality in educational institutions. ABAC Journal, 24(2), 14-25.

Kurnia, S. S. (2017). Jurnalisme Kontemporer. Jakarta: Yayasan Obor Indonesia. 
Lasswell, H. D. (1948). The structure and function of communication in society. The communication of ideas, 37(1), 136-139.

Littlejohn, S. W., \& Foss, K. A. (2010). Theories of Human Communication. Long Grove, Illinois: Waveland press, Inc.

Miller, G. R., \& Steinberg, M. (1975). A new analysis of interpersonal communication. NY: Science Research Associates.

Mulyana, D. M. (2013). Metode penelitian Komunikasi: Contoh-Contoh Penelitian Kualitatif Dengan Pendekatan Praktis. Bandung: Remaja Rosdakarya.

Nasrullah, R. (2018). Komunikasi Antar Budaya: di Era Budaya Siber. Jakarta: Prenada Media.

Nurudin, N. (2020). Pengaruh persepsi kompetensi guru dan persepsi komunikasi interpersonal guru terhadap prestasi belajar. In Prosiding Seminar Nasional Magister Psikologi Universitas Ahmad Dahlan, 46-57.

Panuju, R. (2018). Pengantar Studi (Ilmu) Komunikasi: Komunikasi sebagai Kegiatan Komunikasi sebagai Ilmu. Jakarta: Kencana Prenada Media Group.

Panuju, R. (2019a). Narative Analysis of Perindo Party Advertisement. Jurnal Komunikasi: Malaysian Journal of Communication, 35(3), 41-56.

Panuju, R. (2019b). Komunikasi Pemasaran. Jakarta: Kencana Prenadamedia Group.

Parasuraman, A., Zeithaml, V., \& Berry, L. (2002). Servqual: a multiple-item scale for measuring consumer perceptions of service quality. Retailing: Critical Concepts, 64(1), 140.

Patton, B. R. \& Giffin, K. (1981). Interpersonal Communication in Action: Basic Text and Readings. New York: Harper \& Row Publishers.

Pearson, J. C., Child, J. T., DeGreeff, B. L., Semlak, J. L., \& Burnett, A. (2011). The influence of biological sex, self-esteem, and communication apprehension on unwillingness to communicate. Atlantic Journal of Communication, 19(4), 216-227.

Rakhmat, J., \& Mulyana, D. (2010). Komunikasi Antarbudaya: Panduan Berkomunikasi dengan Orang-Orang Berbeda Budaya. Bandung: Remaja Rosdakarya.

Sari, A. A. (2017). Dasar-Dasar Public Relations Teori dan Praktik. Yogyakarta: Deepublish.

Setyaji, J. (2010). Buku Pintar Menguasai Komputer dan Laptop. Jakarta: Mediakita.

Valkenburg, P. M., \& Peter, J. (2007). Online communication and adolescent well-being: Testing the stimulation versus the displacement hypothesis. Journal of Computer-Mediated Communication, 12(4), 11691182.

Wiryanto, D. (2006). Pengantar Ilmu Komunikasi. Jakarta: Grasindo.

Widjaya, H. A. W. (2000). Ilmu Komunikasi: Pengantar Studi. Jakarta: Rineka Cipta. 